
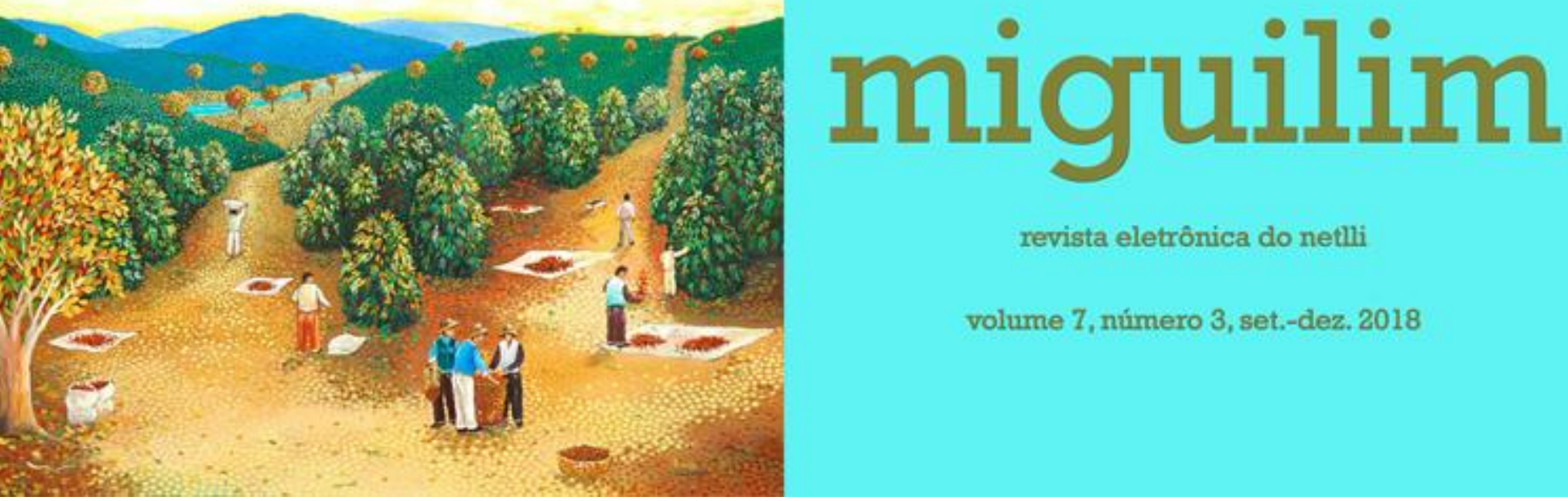

revista eletrônica do netlli

volume 7, número 3, set.-dez. 2018

\title{
BÍA E ANÁNKE EM “FATALIDADE”, DE GUIMARÃES ROSA: ENSAIO TRÁGICO NO SERTÃO.
}

\author{
BIA AND ANANKE IN GUIMARÃES ROSA'S \\ "FATALIDADE": A TRAGIC ESSAY IN THE BACKWOODS.
}

\author{
Fabrício Lemos da COSTA \\ Maria Elizabeth Bueno de GODOY
}

Universidade Estadual do Amapá, Brasil

RESUMO | INDEXAÇÃO | TEXTO | REFERÊNCIAS | CITAR ESTE ARTIGO | O AUTOR

RECEBIDO EM 15/09/2018 • APROVADO EM 09/02/2019

\section{Resumo}

Este artigo tem como objetivo refletir sobre a presença do trágico em Primeiras estórias, de João Guimarães Rosa, colocando-o como uma espécie de "aclimatação" trágica no sertão dos gerais. Para isso, abordaremos os "ecos" do drama antigo a partir do destino/ necessidade (Anánke) e violência (Bía), relacionando-os aos conflitos do sertão. A análise dar-se-á em "Fatalidade", nono conto de Primeiras estórias. Nesse sentido, este texto tem como parâmetro o caráter universal, em que convergem para as estórias primeiras, o qual é possível encontrar-se nos mitos e narrativas literárias antigas, convivendo pelo sertão, em um estado de simplicidade, mas ao mesmo tempo capaz de emergir da riqueza em relação à importância das "estórias" que se perfazem no lugar. 
The present article aims at reflecting upon the presence of the tragic element in João Guimarães Rosa's Primeiras estórias, considered as a sort of tragic environment in Gerais' backwoods. Therefore, one approaches the Greek drama echoes from the concept of destiny/necessity (Ananke) and violence (Bia), relating them to the backwoods' conflicts. The analysis is settled in the ninth of Primeiras estórias' tales intitled "Fatalidade". Thus, the work holds as its parameter the universal character from which they converge to the first narratives, where one might find in the ancient and mythical narratives, living by the backwoods, in its simple state, nevertheless capable of emerging from the richness related to the relevance of the "stories" which develop in this very environment.

Entradas para indexação

PALAVRAS-CHAVE: Guimarães Rosa. Primeiras estórias. "Fatalidade". Tragédia Grega. Anánke. Bía.

KEYWORDS: Guimarães Rosa. Primeiras estórias. "Fatalidade”. Greek Tragedy. Ananke. Bia.

Texto integral

"Ó coração-hoplita, descumprir esse ato horrível, se ananke, o imperativo, o dita?!"

(Medeia, vv.1241-s)

\section{Primeiras estórias: uma introdução}

Primeiras estórias, de João Guimarães Rosa, veio à lume pela primeira vez em $1962^{1}$, constituída de vinte e um contos. Enumeramos na ordem de publicação: "As margens da alegria", "Famigerado", "Sorôco, sua mãe, sua filha", "A menina de lá", "Os irmãos Dagobé", "A terceira margem do rio", "Pirlimpsiquice”, "Nenhum, nenhuma", "Fatalidade", "Sequência", "Os espelho", "Nada e a nossa condição", "0 cavalo que bebia cerveja", "Um moço muito branco", "Luas-de-mel”, "Partida do audaz navegante", "A benfazeja", "Darandina", "Substância”, "_ Tarantão, meu patrão" e "Os Cimos". Primeiras estórias apresentou-se ao público e marcou suas leituras pelo viés de contato entre as culturas mais antigas, a grega por exemplo, as quais passariam a ser em sentido "polifônico" aclimatadas no sertão. Nesse sentido, é que compreendemos a referência ao destino na capa de brochura da editora, em que Anánke ou Avó $\gamma \kappa \eta$ coloca-se em mistura com outros elementos de apresentação, como estrelas, esfinges, palco de teatro, natureza geral sertaneja, com sua flora e fauna abundantes de "estórias". Atentemos para a palavra "Avó $\gamma \kappa \eta$ " na figura abaixo: 


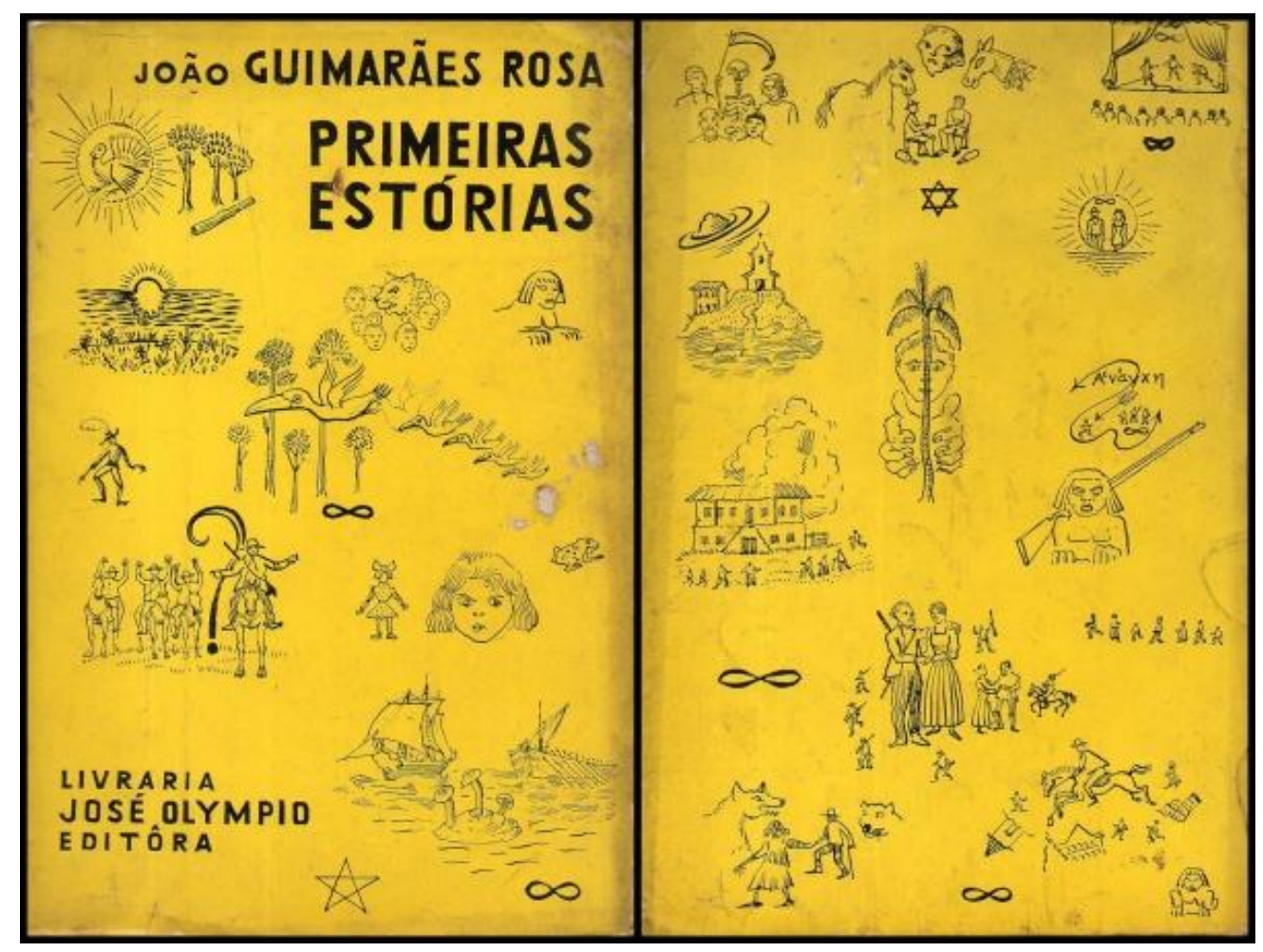

FIGURA 1: Capa em brochura de Primeiras Estórias, de João Guimarães Rosa, ilustrado por Poty. Editora José Olympio. Fonte: www.levyleioeiro.com.br. (Acesso em 05 de Setembro de 2018)

O lugar sertão em Primeiras estórias, dessa forma, é para onde tudo converge em ambivalências, sendo geografia, o ambiente físico, mas ao mesmo tempo, é o espaço cósmico e humano, cujas perguntas e respostas são colocadas na medida em que o sujeito passa a lançar-se à incerteza, ao perigo, ao destino $(\text { Anánke })^{2}$ e à violência (Bía) dos gerais. Todos esses elementos, no entanto, colocam-no na dimensão da violência e do nunca alcance da felicidade plena, pois o homem é abalado pela perigosa vivência do lugar simples. 0 ambiente sertanejo, por outro lado, é para onde a universalidade humana dá-se em demasia, perfazendo-se em sublime, fatalidade, e em tragédia. Luiz Costa Lima em Porque que Literatura, sublinha:

O sertão, portanto, também se faz ambivalente, dupla existência, relação dinâmica, vida situada em dois planos. Não se trata de um ultrapasse, depurando-se o sertão físico em lugar cósmico, em que lugar é o ponto que o homem ocupa, e não este ou aquele de confirmação geográfica. (LIMA, 1969, p.73)

Assim, no sertão de Primeiras estórias, o acaso do destino faz-se em aventura, em que quase sempre o homem encontra-se em atividade de guerra entre grupos ou individualmente, seja por questões relacionadas ao amor, à 
vingança ou à difícil decisão moral. A condição do sertanejo, na maioria jagunços, é o "não-lugar", o caminhar que o leva ao descobrimento de si mesmo, ou ainda, ao acesso da sublimidade e à fatalidade, elaborados pelo fio que costura o destino (moira), e os constrangimentos, ou necessidades, por ele impostos (Anánke). Entretanto, como foi dito anteriormente, a desmesura, a violência, a arrogância (hýbris) estão em toda parte, é o lugar dos mais fortes, daqueles que se sobressaem em estratégias, lutas e interesses particulares, assim como é o espaço propício onde tudo converge à universalidade, a linguagem poética que se realiza em viagem. De acordo com Nunes:

Viajam os personagens rosianos de várias maneiras. Viajam quando pastoreiam, quando plantam, quando gerreiam, quando festejam. A condição deles é andeja. De um pasto a outro, de uma fazenda a outra, conduzem boiadas ou gente. Adotam trabalhos temporários, sazonais. Às vezes são guias de viajantes, não raro andarilhos, vagamundos quase sempre. Mas quase sempre escalando o Sertão-mundo de que não saem. Por isso, nos textos de Rosa, o cômico e o trágico, o reles e o sublime, passam-se a céu aberto. (NUNES, 2013, pp.274-275).

\section{Bía e Anánke: da gênese arcaica ao olhar trágico e filosófico}

Para a plena acepção dos conceitos aqui dispostos à luz da reflexão rosiana, faz-se necessária (natureza mesma de anánke), uma digressão por sua gênese, entre os antigos, não obstante, breve. Destarte, estabeleceu-se, para tal, o recorte que contemplasse sua origem em três obras e fragmentos, a saber: a Teogonia de Hesíodo, para a acepção da gênese de Bía; as teogonias órficas, ou chamadas Rapsódias, para anánke, dos fragmentos da corrente neoplatônica de Damásio, estabelecidos por West ${ }^{3}$; e as recorrências de ambas na tragédia esquileana, Prometeu Acorrentado, recepção datada do século V a.C. O recorte, que também perpassa sua apropriação filosófica entre Platão e Aristóteles, não propõe abarcar o extenso leque de suas recorrências, tampouco esgota o rico cabedal presente na lírica, na poesia, no drama e no corpus filosófico entre os gregos, objetivando minimamente referenciá-los para a pertinência de sua compreensão à luz da reflexão aqui proposta.

Segundo o estabelecido por Ivan Gobry na obra, Vocabulário grego da filosofia, anánke, transliterada de ávó $\gamma \kappa \eta$, e traduzida como coerção, necessidade ou constrangimento, deriva da expressão primeva "decreto inexorável dos deuses". Expressão contemplada em um fragmento de Empédocles, do século V a.C4. Entretanto, conforme o estudo de West, o compêndio da Teogonia Rapsódica Órfica, criado no período helenístico tardio e, por sua vez, derivado de poemas órficos mais antigos, aponta-a como companheira de Kronos, conforme a descrição: "Primeiro era Kronos, eterno tempo, representado como uma serpente alada e unido a Anánke. Ele gerou o Éter e o grande Abismo, sem fundo ou fronteiras, coberto pela escuridão profunda e pela Noite Negra (Nýx)." ${ }^{5}$ Neste sentido, Anánke 
precedendo deuses, mesmo primordiais, estabelece-se imprescindível sobre todos os seres, imortais ou não. Vínculo inflexível, coercitivo que a tudo enlaça. Lembranos Calasso que, "segundo Parmênides, o próprio ser é envolvido pelos vínculos da corda da potente Anánke" (CALASSO, 1990:73), constrição, ora enganadora, ora não, deveras impositiva. ${ }^{6}$

Em seu sentido filosófico, segundo o estabelecido por Aristóteles em seu léxico (Met., $\Delta, 5)$, anánke está contemplada na forma do qualificativo neutro anankaîon: o necessário, cujo sentido divide-se em cinco descrições: (i) a de uma condição sem a qual o ser não subsiste (água; alimento); (ii) a da coerção, associada à bía; (iii) à inflexibilidade ou imutabilidade de sê-lo de outro modo (aqui atribuída, talvez?, à sua gênese primeva); (iv) à necessidade lógica, de qualquer demonstração empírica (apódeixis); e, finalmente, (v) a da necessidade metafísica, segundo Aristóteles, o simples (tò haploûn). Nota Gobry, ainda sobre anánke, a diversidade de sentidos para o conceito em Platão (GOBRY: 2007, 19), dos quais destacamos a necessidade metafísica (Timeu, 42a) e de determinismo cósmico (Timeu, 42e); a de coerção política, contemplada no Livro V da República (Rep., V,519e); e a de destino, ou sorte, das almas (Fédon, 86c), cuja referência nos remete, novamente, à gênese órfica, em que ao destino, ou sorte (moîras), precedem os vínculos da Necessidade (WEST, 1983, 70)7. No terceiro conjunto de fragmentos das Teogonias Órficas contempla-se a gênese; pois, de Nýx (Noite) adviria Uranos de cuja união com Gaia nasceriam as moîras: "Urano casou-se com Gaia, e esta é chamada a primeira união, não obstante a precedente, entre Phanes e Nýx. Gaia pare as Moîras (Klotho, Lachesis e Atropos)", fiandeiras do destino dos seres (WEST, 1983: 71) ${ }^{8}$. Neste sentido, a acepção é análoga a de Hesíodo, não obstante este não mencione a gênese de Anánke (Teog., vv. 211- 220).

Da segunda asserção aristotélica notada por Gobry, anánke surge associada diretamente à coerção, uma das definições de bía. Segundo Hesíodo, Bía (violência) é filha de Estige, da linhagem do céu, gerada por Tétis e Oceano: "Estige filha do

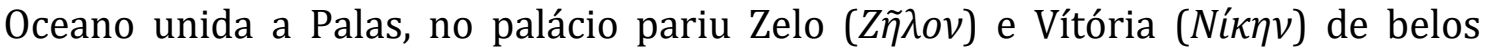

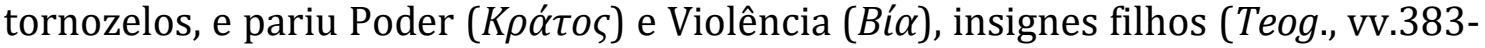
385). Insignes por sua sempiterna aliança com o Cronida, Zeus, a quem Estige os consagrou, honrando-os ao deus para que, ao seu lado, combatessem contra os Titãs, pois,

\author{
Longe deles não há morada de Zeus nem pouso \\ nem percurso por onde o Deus não os guie \\ mas, sempre perto de Zeus gravitronte repousam. \\ Assim decidiu Estige imperecível Oceanina \\ no dia em que o Olímpio relampeante a todos \\ os imortais conclamou ao alto do Olimpo, \\ e disse quem dos Deuses combatesse com ele contra os Titãs \\ ele não o privaria dos prêmios e cada honra \\ manteria como antes entre os Deuses imortais,
}


e que o não-honrado sob Crono e sem-prêmios

honra e prêmio alcançaria, como é justiça.

E veio primeiro Estige imperecível ao Olimpo

Com os filhos, por desígnios de seu pai;

Honrou-a Zeus e supremos dons lhe deu;

fez dela própria o grande juramento dos Deuses

e seus filhos para sempre residirem com ele. (Teog., vv. 386-401)

Doravante parelha divina, jamais apartada de Zeus, em que Bía figura a violência coercitiva, tão bem ilustrada por Ésquilo em sua tragédia Prometeu Acorrentado $^{9}$. 0 mito do astucioso titã Prometeu, tratado tanto na Teogonia (vv. 517-616), quanto em Os Trabalhos e os Dias (vv. 42-105), de Hesíodo, versa sobre suas manobras dolosas contra Zeus. Entre outros, o roubo do fogo, entregue à raça dos homens, cujas consequências impõe-lhe o duro castigo: ser acorrentado à rocha escarpada por Hefesto (deus das forjas), sob o implacável jugo e coerção de Bía, personagem muda, e Krátos. A mudez de Bía enfatiza a potência que a define; acompanhada de seu irmão, o poder (Krátos), lhe fortalece o implacável discurso, fazendo cumprir o determinado por Zeus (Prometeu, vv.1-s).

Ao longo do drama o titã narra sua sorte ao Coro, composto pelas ninfas do Oceano, e ao próprio Oceano e Io (perseguida pela fúria da ciumenta Hera), e entre vaticínios e constatações, reitera, também, a presciência e inexorabilidade dos nós de anánke sobre o lote de todos. Destacam-se alguns versos neste sentido, como em (Prometeu, vv. 103-s), onde o ardiloso titã reitera sua resiliência e aceitação diante do inescapável jugo da Necessidade, "que não conhece resistência". Do diálogo com as ninfas, Ésquilo destaca os domínios de anánke sobre a sorte dispensada ao titã, cujas astuciosas habilidades não lhe podem alterar, aplacar ou resistir, destino cumprido pelas moîrai e Erínias (Prometeu, vv.510-s). Jugo ao qual não escapa, mesmo sendo, ele também, de natureza imortal (Prometeu, vv. 1050-s).

Assim contemplada na apropriação entre os gregos antigos, desde sua gênese, na tradição órfica (a posteriori codificada pela tradição helenística), e na poesia de Hesíodo, ao amplo leque oferecido pelo drama grego (aqui brevemente visto na tragédia de Ésquilo), e à sua recepção filosófica, entre Platão e Aristóteles, passa-se à apropriação poética e literária na narrativa rosiana, debruçada sobre a fatalidade e os entrelaçamentos coercitivos de anánke e bía.

\section{3. "Fatalidade": "estória" de perseguição e violência}

Para esta reflexão, discutiremos a "estória" de Zé Centeralfe, sujeito simples do sertão, que se vê perseguido por Herculinão, homem violento dos gerais, que começa a cortejar de forma desonrosa a mulher do primeiro. Zé Centeralfe, para livrar-se do "Don Juan" sertanejo resolve mudar-se de cidade ${ }^{10}$, no entanto, de imediato, verificara que o plano não dera certo, levando-o à necessidade do auxílio 
de Meu Amigo, pois é "de vasto saber e pensar, poeta, professor, ex-sargento de cavalaria e delegado de polícia."11 $(F$, p.107). Em "Fatalidade"12, a violência (Bía) encontra-se em toda parte, desenvolvendo-se em primeiro plano nas relações entre os sujeitos que fogem, perseguem e cometem vingança. Vejamos um fragmento inicial da narrativa, a qual se coloca a visita de Zé Centeralfe ao Meu Amigo: "Foi o caso que um homenzinho, recém-aparecido na cidade, veio à casa do Meu Amigo, por questão de vida e morte, pedir providência.” (Ibidem, p.107).

A violência em $F$ dá-se em armadilhas, isto é, em planos estratégicos de vingança, nesse sentido, compreendemos a visita de Zé Centeralfe, homem que acredita na lei (Nómos), mas se vê desprotegido em situação de perseguição cotidiana nos gerais: "Sou homem de muita lei...Tenho um primo oficial-dejustiça...Mas não me abrange socorro...Sou homem de muita ordem...13" (Ibidem, p.08). Zé Centeralfe, mesmo acreditando na lei, resolve partilhar da maneira comum do lugar, ou seja, da violência em suas variadas possibilidades. Assim, o personagem arma-se, e juntamente com Meu Amigo, sai no encalço de Herculinão, o Hércules do sertão. Para isso, invoca aquele que sabia manejar de armas, Meu Amigo: "Estava-se em seu fundo de quintal, exercitando ao alvo, com carabinas e revólveres, revezadamente. Meu Amigo, a bom seguro que, no mundo, ninguém, jamais, atirou quanto ele tão bem- no agudo da pontaria e rapidez em sacar arma." (Ibidem, p.107).

\section{Meu Amigo: um discurso em favor de Anánke}

Em $F$, Meu Amigo discursa em favor ${ }^{14}$ de Anánke, do destino, sendo a soma dos fatos que se colocam em situação de violência no sertão. Assim, os sujeitos estão imersos pela força dos fios das fiandeiras, as Moiras, (Moı̃ $\alpha \iota)$, as quais decidem o desenrolar dos acontecimentos. Meu Amigo, como já se disse, é "de vasto saber e pensar, poeta, professor" (Ibidem, p.107), cuja sabedoria eleva a narrativa para as perspectivas mais universais da cultura, numa espécie de retorno ao pensamento mais antigo, a época arcaica grega, momento que os helenos vivenciavam a vida como o tecer e divisão das partes que cabe a cada um. Meu Amigo, argumenta: "Só quem entendia de tudo eram os gregos. A vida tem poucas possibilidades." (Ibidem, p.107). Dessa forma, o destino encontra-se na clave da "estória", é para onde tudo converge.

Por outro lado, além de pensador e ligado aos helenos, sendo "Fatalista como uma louça" ( $F$, p.107), Meu Amigo é ligado à violência, justificando-a no perigo do sertão, e para isso, "gastava nisso, por dia, caixas de bala" (Ibidem, p.107). Meu Amigo, tinha consciência, ao que parece, da existência de toda a violência (Bía) no lugar, emaranhando-se com o destino, como é possível verificar desde os antigos, cuja adoração em Corinto [Anánke e Bía], dá-se em um mesmo plano. A referência às duas desenvolve-se no discurso de Meu Amigo por "aclimatação", são os valores antigos perfazendo-se em ambiente simples, os gerais. Vejamos mais um trecho do discurso de Meu Amigo: "Se o destino são componentes consecutivos- além das circunstâncias gerais de pessoa, tempo e lugar..." (Ibidem, p.108). Além disso, vale ressaltar, que o discurso do personagem, 
dá-se em "polifonia", traço comum na ficção de Guimarães Rosa, porque para o sertão tudo converge. Em $F$, o destino é invocado, no entanto, a graça ${ }^{15}$, isto é, o livre-arbítrio da teologia cristã, quando necessária, é também colocada em evidência: “_Não estamos debaixo da lei, mas da graça...” _ Cuido que citasse epístola de São Paulo." (Ibidem, p.108)

O destino e a violência aclimatam-se no sertão, assim como inserem a ficção de Guimarães Rosa na conjuntura universal trágica, cuja relação interpõe-se entre os principais enredos de dramas gregos e a incerteza dos gerais. Portanto, o sujeito em $F$, ora erra por Necessidade (Anánke), ora flerta com o livre-arbítrio, é o sertão saltando em "polifonia", entretanto, prevalece, ao que indica a narrativa, o tom do destino pelas falas de Meu-Amigo, o qual ensaia no simplório ambiente, um acontecimento de fatalidade dramática. Dessa forma, o que nos coloca em permissão de lê-la nos "ecos" da cultura grega antiga, dá-se em linguagem, no interior do discurso, como se desenvolve em "A benfazeja", na qual o narrador direciona e ensaia o trágico na "estória" da mulher que assassina o marido e o enteado com o objetivo de salvar a comunidade da violência de Mumbungo, seu esposo. Rachel Gazolla em Para não ler ingenuamente uma tragédia grega, argumenta:

\begin{abstract}
Assim, não sendo possível saber o que se deve seguir por si mesmo, não se afirma o erro com o sentido de culpa. Ou, dito de outro modo, se o homem é levado a errar por imposição de uma ordem que o transcende, pela Anankê (Necessidade) ou pela Moira, ou por ignorância, não há por que punir-se individualmente. (GAZOLLA, 2001, p.70)
\end{abstract}

Ao homem trágico antigo não é permitido a fuga do destino, Moiras e Anánke trabalham juntas, levando os homens para o bem ou para o mal, entretanto, entre o destino e o homem, coexiste também a vontade do herói 16 , convertido em persuasão. Arriscamo-nos a dizer, que tal vontade é de mais fácil compreensão para os homens atuais, na qual se inclui, na nossa cultura, a própria noção de livre-arbítrio e decisão i(moral). Em $F$, o destino, a persuasão, sobretudo com Meu Amigo, assim como a vontade desenvolvem-se em aclimatação, e ao sertanejo, cabe emergir e vivenciar em demasia. Vale lembrar, novamente, que estamos a falar de uma espécie de ensaio trágico nos gerais, cuja noção leva-nos a conceber a possibilidade em experiência dramática pela linguagem. Rachel Gazolla sublinha sobre a existência da persuasão do herói na tragédia, mesmo com Anánke e Moiras agindo em tessitura:

Os gregos sabem que não é possível afastar Moira e Anánke, e nenhum poeta trágico ousaria enunciar tal fato, mas é assinalado o poder da persuasão como o outro lado a ser exercido pelo homem comum. Em particular, exatamente porque não se sabe sobre o próprio destino, há que haver cuidado em tratar da própria vida 
exigente de persuasão interna diante do que acontece. (Ibidem, p.77)

\section{5. "Fatalidade": violência (Bía) e "cordialidade" no sertão.}

Em $F$, a violência (Bía) desenvolve-se no jogo dos mais fortes e na construção de relações, ou seja, em apadrinhamentos, como é o caso da formação de jagunços, na luta por poder pela terra, por exemplo. As relações constroem-se com base na desmesura (hýbris), em que os percalços colocam-se em fatalidade, muitas vezes. A violência dá-se em nascedouro de hýbris, assim como insere o homem em trágicas situações, ensaiando dramáticos momentos no sertão, desenvolvendo-se em conflitos ${ }^{17}$, vinganças e mortes. Os conflitos que emergem no trágico desencadeiam-se em sentimentos, envolvidos em destino e temor ${ }^{18}$. Werner Jaeger em Paideia, argumenta:

A participação sentimental no desencadeamento do destino, que já Sólon comparava a uma tormenta, exigia a mais alta força espiritual para lhe residir e despertar, contra o medo e a compaixão, seus efeitos psicológicos imediatos, a fá no sentido último da existência. (JAEGER, 1995, p.297).

Os conflitos em $F$, nascidos do insulto e insolência, levam a narrativa para a fatalidade, morte de Herculinão, e a criação de laços entre parceiros, como é possível verificar na relação entre Meu Amigo e Zé Centeralfe, perfazendo-se em uma polidez de "homem cordial", como define Sérgio Buarque de Holanda em Raízes do Brasil: "A lhaneza no trato, a hospitalidade, a generosidade, virtudes tão gabadas por estrangeiros que nos visitam, representam, com efeito, um trato definido do caráter brasileiro." (HOLANDA, 1995, p.146). Além disso, a cordialidade converte-se virtude antiga, em tratar bem os amigos e mal os inimigos, o que nos explica o envolvimento entre Meu Amigo e Zé Centeralfe:

0 qual, vendo-se que caipira, ar e traje. Dava-se de entre vinte-emuitos e trinta anos; devia de ter bem menos, portanto, Miúdo, moído. Mas concreto como uma anta, e carregado o rosto, gravado, tão submetido, o coitado; as mãos calosas, de enxadachim. Meu Amigo, mandando-lhe sentar e esperar, continuou, baixo, a conversa; fio que, apenas para poder observar o outro, vez a vez, com o rabo-do-olho, aprontando-lhe a avaliação $(F, \mathrm{p} .108)$

\section{Vingança e fatalidade: "Amor ao amigo, rigor contra o inimigo; eis o que glorifica a vida!"}


Zé Centeralfe e Meu Amigo, saem no encalço de Herculinão, armados saltam ao perigo e à luta (Agón), os quais mergulhados e levados pelo destino, como acredita Meu Amigo, preparam-se ${ }^{19}$ para o desfecho: fatalidade. Ambos caminham para o momento do demasiado, à morte e ao temor final. A verdade é que todos excedem no jogo dos interesses, Herculinão, por exemplo, excede, caindo em erro e desgraça, estivera desde sempre nas teias da necessidade e do destino: "Viajamos para cá, e ele, nos rastros, lastimando a gente. É peta. Não me perdeu de vistas. Adonde vou, o homem me atravessa...20" ( $F$, p.110). Assim, Meu Amigo, ensaia o trágico na existência de Herculinão, inserindo-o no dramático grego, isto é, a partir daquilo que já está escrito por necessidade (Anánke): "Meu Amigo, não. Disse um 'oh' polissilábico, sem despesas de emoção. Disse:_ 'Tudo não é escrito e previsto? Hoje, o deste homem. Os gregos...' Disse:_ 'Mas... a necessidade tem mãos de bronze..." (Ibidem, p.112). Heloisa Vilhena de Araújo em O Espelho: contribuição ao estudo de Guimarães Rosa, argumenta em relação ao estado do demasiado em Herculinão, pensando-o como Hércules:

\begin{abstract}
Seu nome lembra o de Hércules, herói grego, filho de Zeus e Anfitrião, pois sua mãe, Alcmena, recebera a visita do deus e do homem na mesma noite. Hércules, portanto, excede a condição humana, incorrendo no ressentimento de Hera por sua origem semidivina. Incorre na hýbris, na insolência de uma origem excessiva, além da humana, e Zeus retira-lhe a razão. Nesse excessus mentis, Hércules mata, sem saber seus filhos e sua mulher, Megara, o que foi objeto da tragédia Hércules Furens, de Eurípides. (ARAÚJO, 1998, p.107)
\end{abstract}

Herculinão, ao lembrar o herói grego, é imerso no excesso, desde o momento em que começara a perseguir José Centeralfe e a esposa desse último. Do excesso de Herculinão, é que termos o início de uma "amizade" entre Meu Amigo, cujo nome é sugestivo, e Zé, relação que nascera do mesmo sentimento no que tange à atitude de Herculinão, convertendo-se em virtude antiga ${ }^{21}$, como percebemos na fala de Ajax (Al̈ $\alpha$ ) da tragédia Aias, de Sófocles: "Mas eu, eu acabo de descobrir que / o inimigo por nós deve ser odiado tanto / quanto nos amará de volta e que ao amigo / quererei, servindo, ajudar, na medida/ que não o será sempre: para a maior parte / dos mortais é infiel o porto da camaradagem." (Aias, vv.678-684). Segundo Aristóteles: "A camaradagem, a familiaridade, o parentesco e outras relações semelhantes são espécies de amizade. Um favor produz amizade, tal como o fazê-lo sem ser solicitado e sem ostentar que se fez, pois assim parece que se fez só por causa do favorecido e não por outro motivo qualquer. (ARISTÓTELES, Retórica, II, 1381 b). Por outro lado, Herculinão, para Meu Amigo, é levado pela ira, justifica-se sua morte: “_ Sigamos o nosso carecido Aquiles...” (F, p.111), lembra-o, novamente em discurso, o personagem homérico, Aquiles ${ }^{22}$, o qual se coloca em ira, perseguindo individualmente seus inimigos, quase nunca o coletivo. Ainda de acordo com Aristóteles: 
Vamos admitir que a ira é um desejo acompanhado de dor que nos incita a exercer a vingança explícita devido a algum desprezo manifestado contra nós, ou contra pessoas da nossa convivência, sem haver razão para isso. Se a ira é isto, forçoso é que o iracundo se volte sempre contra um determinado indivíduo, por exemplo contra Cléon, mas não contra o homem em geral; e que seja por algum agravo que lhe fizeram ou pretendiam fazer, a ele ou a algum dos seus; além disso, toda ira é acompanhada de certo prazer, resulta da esperança que se tem de uma futura vingança. De fato, existe prazer em pensar que se pode alcançar o que se deseja. (ARISTÓTELES, Retórica, II, 1378 b)

\section{Considerações Finais}

Primeiras estórias, de João Guimarães Rosa, elabora-se em "estórias primeiras", ou seja, em "ecos" de narrativas primordiais antigas, como os enredos trágicos, mencionados neste artigo. Em "Fatalidade", a "estória" emerge do conflito, violência e desmedida, que são aclimatadas em contexto de sentimento brasileiro, ou seja, "o homem cordial", o qual emana do polifônico discurso de Meu Amigo, cujo o Destino e a Necessidade (Anánke), jorram da sabedoria do personagem que tem "vasto saber e pensar" ( $F$, p.107). Nesse sentido, compreendemos o desfecho de "Fatalidade", final que se coloca em terror, morte e cumprimento do destino por necessidade, de acordo com a visão de Meu Amigo.

A morte de Herculinão, justifica-se em ira, assim como em amizade construída entre os personagens Meu Amigo e Zé Centeralfe, desenvolvendo-se, nesta perspectiva, em tratamento adequado ao amigo e violência (Bía) em relação ao inimigo. Dessa forma, a cordialidade de Meu Amigo, perfaz-se em pensamento antigo, "Amor ao amigo, rigor contra o inimigo; / eis o que glorifica a vida!" (Medeia, vv.808-810), mas ao mesmo em experiência no perigoso modo de viver do sertão ficcional de Rosa, lugar onde requer astúcia e força, tamanho é sua instabilidade: "E ... foi: fogo, com rapidez angélica: e o falecido Herculinão, trapuz, já arriado lá, já com algo entre os próprios e infra-humanos olhos, lá nele_tapando o olho-da-rua. Não há como o curso de uma bala; e _ como és bela e fugaz, vida" $(F$, p.111).

\section{Notas}

${ }^{1}$ Cf. COUTINHO, 2013, p.12: “O livro seguinte de Guimarães Rosa foi lançado em 1962, com o título de Primeiras Estórias. Trata-se de uma coleção de 21 pequenos contos, em que o autor, deixando de lado a caudalosidade de seu Grande Sertão: Veredas, destaca-se justamente pela contenção, densidade e economia da linguagem. Como os anteriores, o livro alcançou também expressivo êxito e foi muito bem recebido pela crítica." 
${ }^{2}$ Vale ressaltar que Anánke não se reduz ao sentido de destino, redimensionando-se em uma contemplação plurissignificativa. Por exemplo, na cosmogonia órfica, Anánke é a necessidade. Abordaremos com maiores detalhes na segunda seção desse estudo.

${ }^{3}$ Segundo West, Damásio, último líder da Escola Neoplatônica de Atenas, identificou três teogonias órficas distintas, ou poemas, aos quais denomina Rapsódias. Para o argumento completo ver: WEST, M. L. The Orphic Poems. Oxford University Press, 1983, pp.68-9.

4 EMPÉDOCLES, fr. 125-126, apud GOBRY, I. Vocabulário grego da filosofia. Tradução Ivone C. Benedetti. São Paulo: wmf Martins Fontes, 2007, p. 19.

5 "First was Unaging Time (60, cf. 54, 68), represented as a winged serpent and coupled with Ananke (Arg. 12f., cf. fr. 126, Hym 12.10). He generated Aether and huge Chasm, without bottom or boundary $(66,54,60)$, overlaid with gloomy darkness and Night." WEST, M.L. op.cit., 1983, p. 70. (A tradução é nossa).

${ }^{6}$ CALASSO, R. As núpcias de Cadmo e Harmonia. Tradução Nilson Moulin Louzada. São Paulo: Companhia das Letras, 1990.

${ }^{7}$ Os grifos são nossos.

8 'Uranos marries Ge, and this is called the first marriage, Phanes' union with Night being discounted (112). Ge gives birth to the Moirai (Klotho, Lachesis and Atropos), (...)", em: WEST, op.cit., 1983, p.71.

${ }^{9}$ Utilizou-se neste artigo a tradução estabelecida por Sotto Mayor para a língua portuguesa: ÉSQUILO. Prometeu Agrilhoado. Lisboa: Edições 70, 1992.

${ }^{10}$ Cf. F, p.109: "Sucedendo-se os sustos e vexames, não acharam outro meio. Ele e a mulher decidiram de mudar. _ 'Sendo para a pobreza da gente um cortado e penoso. Afora as saudades de se sair do Pai-do-Padre; a gente era de muita estimação lá'. Mas, para considerar Deus, e não traspassar a lei, o jeito era. _ 'Larguei para o arraial do Amparo...' Arranjaram no Amparo uma casinha, uma roça, uma horta."

${ }^{11}$ Todas as citações de "Fatalidade" se referem a essa edição (15a ed.) e serão indicadas pela abreviatura $F$, seguida do número da página.

${ }^{12}$ Após essa citação de "Fatalidade" no corpo do texto, utilizaremos a abreviatura $F$.

13 O grifo é nosso.

${ }^{14}$ Cf. ARAÚJO, 1998, p.109: “Meu Amigo, portanto, menciona, com relação aos gregos, o destino e a necessidade. O Zé, por sua vez, quer ver cumprida a lei. O delegado é, na verdade, o encarregado, na cidadezinha, de fazer com que a cumpram. E essa lei, para ele, 'fatalista como uma louça', parece ser a lei do Destino."

${ }^{15}$ Cf. AgOStINHO, De lib.arb., II,1,1: "Se possível, explica-me agora a razão pela qual Deus concedeu ao homem o livre arbítrio da vontade, já que, caso não o houvesse recebido, o homem certamente não teria podido pecar".

${ }^{16}$ Cf. GAZOLLA, 2001, pp.77-78: “Quando utilizamos a expressão vontade do herói para falar de sua ação, com certeza falamos anacronicamente. Não há como contornar Anánke, ela diz 
respeito ao próprio modo constitutivo de ser de cada um, de seu lote que nem mesmo os deuses podem quebrar."

${ }^{17}$ Em $F$, o conflito instala-se na vida de Zé Centeralfe e sua esposa, os quais são perseguidos por Herculinão. A perseguição ocasiona em mudança e intranquilidade, estágios comuns no perigoso sertão, onde tudo rola ao incerto. Cf. F, p.108: "Representou: que era casado, em face do civil e da igreja, sem filhos, morador no arraial do Pai-do-Padre. Vivia tão, com a mulher, que tirava divertimento do comum e no trabalho não compunha desgosto. Mas, de mandado do mal, se deu que foi infernar lá um desordeiro, vindico, se engraçou desbrioso com a mulher, olhou para ela com olho quente..."

${ }^{18}$ Cf. ARISTÓTELES, Poética, VI, 1449 b: “É, pois, a tragédia imitação de uma ação de caráter elevado, completa e de certa extensão, em linguagem ornamentada e com as várias espécies de ornamentos distribuídos pelas diversas partes [do drama], [imitação que se efetua] não por narrativa, mas mediante atores, e que, suscitando o terror e a piedade, tem por efeito a purificação dessas emoções."

${ }^{19}$ Cf. F, p.110: “Por conta daquele. _ 'Cujalma!'_ proferiu Meu Amigo, meticuloso indo ajeitar uma carabina, que se exibia, oblíqua, na parede. Pois a sala_ de tão repleta de: rifles, pistolas, espingardas _ semelhava-se o que nunca se vê. _ 'Esta leva longe...' _ disse, e riu, um tanto malignamente. Tornou-se a sentar-se, porém, sorrindo agradado para o José Centeralfe."

${ }^{20}$ O grifo é do autor.

${ }^{21}$ Podemos ainda recorrer à República, de Platão, em sua discussão de Justiça, sobretudo no que diz respeito ao trato do inimigo. Cf. República, I, 332 b: "E então? E para os inimigos? Teremos de devolver o que lhes devemos? Sem dúvida, respondeu. O que Ihes devemos; mas, segundo o meu modo de pensar, qualquer pessoa só deve ao inimigo o que lhe convém, a saber, algum mal."

${ }^{22}$ Cf. llíada, vv. 01-07: "A ira, Deusa, celebrada do Peleio Aquiles, / o irado desvario, que aos Aqueus tantas penas / trouxe, e incontáveis almas arrojou no Hades / de valentes, de heróis, espólio para os cães, / pasto de aves rapaces: fez-se a lei de Zeus; / desde que por primeiro a discórdia apartou / o Atreide, chefe de homens, e o divino Aquiles."

\section{Referências}

AGOSTINHO, Santo. O livre-arbítrio. 2aed. Tradução, organização, introdução e notas Nair de Assis Oliveira. São Paulo: Paulus, 1995.

ARAÚJO, Heloisa Vilhena de. O Espelho: contribuição ao estudo de Guimarães Rosa. São Paulo: Mandarim, 1998.

ARISTÓTELES. Poética. Tradução, Prefácio, Introdução, Comentários e Apêndices de Eudoro de Sousa. 4ãedição. Lisboa: Imprensa Nacional- Casa da Moeda, 1994.

Retórica. Tradução de Manuel Alexandre Júnior, Paulo Farmhouse Alberto e Abel do Nascimento Pena. São Paulo: Martins Fontes, 2012. 
Metafísica. Vols. I, II, III. Tradução do grego, introdução e comentário Giovanni Reali. São Paulo: Edições Loyola, 2001.

COUTINHO, Eduardo F. Grande Sertão: Veredas. Travessias. São Paulo: Realizações Editora, 2013.

ÉSQUILO. Prometeu Agrilhoado. Tradução de Sotto Mayor. Lisboa: Edições 70, 1992.

EURÍPIDES. Medeia. Introdução, posfácio e notas de Trajano Vieira e comentário de Otto Maria Carpeaux. São Paulo: Editora 34, 2010.

GAZOLLA, Rachel. Para não ler ingenuamente uma tragédia grega. São Paulo: Edições Loyola, 2001.

GOBRY, Ivan. Vocabulário grego da filosofia. Tradução de Ivone C. Benedetti. São Paulo: Wmf Martins Fontes, 2007.

HESÍODO. Teogonia. A Origem dos Deuses. Estudo e Tradução de Jaa Torrano. 5a edição. São Paulo: Editora lluminuras, 2003.

Iluminuras, 1990.

Os Trabalhos e os dias. Tradução Mary de Camargo Neves Lafer. São Paulo:

HOMERO. Ilíada. Tradução de Haroldo de Campos e Introdução e organização de Trajano Vieira. 4a edição. São Paulo: Arx, 2003.

HOLANDA, Sérgio Buarque de. Raízes do Brasil. 26ạ edição. São Paulo: Companhia das letras, 1995.

JAEGER, Werner. Paidéia. A Formação do Homem Grego. Tradução de Artur M. Parreira. 3aed. São Paulo: Martins Fontes, 1995.

LIMA, Luiz Costa. Por que literatura. Petrópolis: Vozes, 1969.

NUNES, Benedito. O mito em Grande Sertão: veredas. In: NUNES, Benedito. A Rosa o que é de Rosa: Literatura e Filosofia em Guimarães Rosa. Victor Sales Pinheiro (Org.). Rio de Janeiro: DIFEL, 2013, pp.218-232.

PLATÃO. A República. Tradução de Carlos Alberto Nunes e Prefácio e Introdução de Benedito Nunes. 3ạ edição. Belém: EDUFPA, 2000.

. Timeu - Crítias. O Segundo Alcibíades. Hípias Menor. Tradução direta do grego Carlos Alberto Nunes. 3a Edição revisada. Belém, PA: Editora UFPA, 2001.

Protágoras. Górgias - Fedão. Tradução direta do grego Carlos Alberto Nunes. 2 a Edição revisada. Belém, PA: Editora UFPA, 2002.

SÓFOCLES. Aias. Apresentação e Tradução de Flávio Ribeiro de Oliveira. São Paulo: Iluminuras, 2008.

ROSA, João Guimarães. Primeiras Estórias. Rio de Janeiro: Nova Fronteira, 2001.

WEST, M.L. The Orphic Poems. Oxford University Press, 1983. 


\section{Para citar este artigo}

COSTA, Fabrício Lemos da; GODOY, Maria Elizabeth Bueno de. Bía e Anánke em "Fatalidade", de Guimarães Rosa: ensaio trágico no sertão. Miguilim - Revista Eletrônica do Netlli, Crato, v. 7, n. 3, p. 561-575, set.-dez. 2018.

\section{Os autores}

Fabrício Lemos da Costa é especialista em Produção de Material Didático e Formação de Mediadores de Leitura para EJA pela UNIFAP-AP, graduado e licenciado em Letras - Língua Portuguesa pela UFPA-PA e graduando em Licenciatura em Filosofia pela UEAP-AP.

Maria Elizabeth Bueno de Godoy é professora substituta do Colegiado de Filosofia da UEAP-AP, doutora em História Social pela FFLCH-USP, mestre em História Social da Cultura pela PUC-Rio e graduada e licenciada em História pela PUC-Rio. 